\title{
SIKAP MEMBER FITNESS CENTER GOR FIK UNY TERHADAP PROGRAM-PROGRAM LATIHAN KEBUGARAN
}

\author{
Oleh: Abdul Majid Sidik dan Suharjana \\ FIK UNY
}

\section{Abstrak}

Penelitian ini bertujuan mengetahui sikap member Fitness Center GOR FIK UNY Yogyakarta terhadap program-program latihan kebugaran. Sikap tersebut didasarkan pada komponen kognitif, komponen afektif, dan komponen konatif.

Penelitian ini merupakan penelitian deskriptif menggunakan metode survei. Sampel dalam penelitian ini adalah member fitness di Fitness Center FIK UNY Yogyakarta yang berjumlah 40 orang, dengan intrumen yang digunakan berupa angket. Untuk menganalisis data digunakan teknik deskriptif kuantitatif dengan persentase.

Hasil penelitian diketahui sikap member fitness center di GOR FIK UNY Yogyakarta sebagian besar berkategori sangat setuju sebanyak 33 orang $(82,5 \%)$ dan frekuensi variabel sikap member fitness pada kategori setuju sebanyak 7 orang $(17,5 \%)$. Data tersebut menunjukkan bahwa kecenderungan data berpusat pada kategori sangat setuju. Dengan demikian dapat disimpulkan bahwa sikap member fitness center di GOR FIK UNY Yogyakarta termasuk dalam kategori positif.

Kata Kunci: Sikap member fitness, program latihan kebugaran

Latihan beban di masyarakat saat ini merupakan olahraga fisik yang banyak digemari oleh masyarakat. Hal ini dibuktikan dengan menjamurnya gedung-gedung fitness center yang berada di tengah-tengah masyarakat. Semua kalangan turut serta dan berpartisipasi, mulai masyarakat bawah sampai kalangan atas. Latihan beban untuk kesehatan dan penampilan sudah menjadi kegiatan yang sangat terkenal di masyarakat tidak hanya pada kalangan muda bahkan bagi yang lebih tua. Alasannya sangat sederhana. Latihan ini secara dramatis menghasilkan tenaga yang lebih baik, otot-otot yang menonjol, dan perbaikan bentuk tubuh. Kini sudah banyak orang melakukan latihan beban secara teratur yang mungkin berbuat demikian karena satu atau lebih alasan untuk meningkatkan status kesehatan, untuk mengubah tubuh mereka demi penampilan, untuk bertanding serta penampilan yang atletis.

Setiap fitness center menyediakan program-program latihan untuk member fitness, seperti program latihan untuk kebugaran, program latihan untuk penurunan berat badan, program latihan untuk penambahan berat badan, program latihan untuk pengencangan, program latihan untuk hipertrofi otot, dan program latihan untuk pemulihan cedera.

Keberhasilan latihan adalah hal yang diharapkan oleh para member fitness. Meskipun 


\section{MEDIKORA Vol. XIV No. 1April 2015}

demikian, tidak sedikit orang mengalami kegagalan dalam mencapai keberhasilan yang ingin dicapai, bahkan ada yang sudah melakukan latihan dengan kurun waktu lama tidak mendapatkan hasil yang diharapkan. Untuk mencapai keberhasilan tersebut, orang harus memahami kunci keberhasilan dalam latihan beban. Banyak orang mengabaikan kunci keberhasilan tersebut. Adapun kunci keberhasilan tersebut meliputi:

Pertama, berlatih secara teratur. Karena salah satu prinsip latihan yaitu prinsip berkebalikan (reversibilitas). Kemampuan otot yang telah dicapai akan berangsur-angsur menurun, bahkan bisa hilang sama sekali, jika tidak latihan. Kualitas otot akan menurun kembali apabila tidak dilatih secara teratur dan kontinu. Oleh Karena itu, rutinitas latihan mempunyai peranan penting dalam menjaga kemapuan otot yang telah dicapai (Suharjana, 2007: 23-24).

Kedua, penambahan intensitas latihan secara perlahan. Tubuh akan menyesuaikan diri terhadap tekanan-tekanan karena latihan beban apabila latihan dilakukan secara teratur, dan apabila intensitas latihan meningkat secara bertahap dalam jangka waktu yang cukup. Sebaliknya, apabila intensitas latihan dilakukan secara tidak teratur, kemampuan tubuh untuk menyesuaikan menjadi lebih kuat serta menjadi lebih bertahan dan dipaksa untuk menerima keadaan.

Ketiga, kualitas pelaksanaan latihan. Tampaknya banyak orang percaya bahwa pengulangan dalam suatu latihan sama dengan peningkatan kemajuan, tanpa memperdulikan program dalam latihan. Dalam program latihan yang dirancang untuk tujuan tertentu, harus dengan takaran yang sesuai agar tujuan yang diinginkan tercapai.

Keempat, asupan gizi. Gizi juga merupakan faktor utama. Tidak ada gunanya berlatih secara berat jika orang tidak memakan makanan yang bergizi. Kekurangan gizi sendiri dapat mengurangi tenaga, ketahanan otot, serta hipertrofi otot, karena latihan banyak menuntut pada tubuh, dan tubuh membutuhkan makanan yang bergizi untuk dapat beradaptasi serta menjadi lebih baik. Mengabaikan aspek ini dalam program latihan sudah pasti akan merugikan apabila orang bersungguh-sungguh untuk berkembang.

Kelima, istirahat yang cukup. Hari-hari istirahat yang terdapat dalam program latihan sangat penting untuk penambahan tenaga, ketahanan otot, serta ukuran otot. Latihan berhari-hari secara berturut-turut tanpa istirahat yang dibutuhkan tubuh untuk beradaptasi, dapat menyebabkan cedera, atau berkurangnya latihan.

Program-program latihan harus diperhatikan dalam latihan beban. karena setiap program latihan memiliki tujuan dan manfaat masing-masing yang saling berkaitan. Member fitness center masih jarang yang mengetahui tentang program-program latihan serta masih sedikit yang melaksanakan program-program latihan tersebut, bukan hanya masyarakat awam, bahkan atlet pun masih banyak yang belum mengetahui program-program-program latihan tersebut.

Menurut pemaparan di atas, program-program latihan tersebut memiliki manfaat masingmasing yang sama-sama penting dalam latihan kebugaran jasmani atau latihan beban. 


\section{MEDIKORA Vol. XIV No. 1April 2015}

Member fitness jarang yang mengetahui dan jarang yang melakukan latihan sesuai dengan pedoman tersebut. Berdasarkan permasalahan tersebut, perlu adana suatu penelitian yang bertujuan untuk mengetahui sikap member Fitness Center GOR FIK UNY Yogyakarta terhadap program-program latihan kebugaran.

\section{SIKAP}

\section{Pengertian Sikap}

Muhadjir dalam (Sumarjo dan Suharjana, 2007: 7) menyatakan bahwa sikap merupakan ekspresi efek seseorang pada objek sosial tertentu yang mempunyai kemungkinan rentangan dari suka sampai tak suka atau setuju sampai tidak setuju pada sesuatu obyek. Sedangkan menurut Kerlinger dalam (Sumarjo dan Suharjana, 2007: 7) sikap adalah kecendrungan yang tertata untuk berfikir, merasa, berperilaku terhadap sesuatu himpunan fenomena seperto obyek-obyek fisik, kejadian atau perilaku.

Berkowitz dalam (Saifuddin Azwar, 1995: 4-5); Louis Thrustone (1928), Rensis Likert (1932), dan Charles Osgood. Menyatakan bahwa, sikap adalah suatu bentuk evaluasi atau reaksi perasaan. Sikap seseorang terhadap suatu objek adalah perasaan mendukung atau memihak (favorable) maupun perasaan tidak mendukung atau tidak memihak (unfavorable) pada objek tersebut. Mengikuti skema triadik, struktur sikap terdiri atas tiga komponen yang saling menunjang yaitu komponen kognitif (cognitive), komponen afektif (affektive), dan komponen konatif (conative).

Kecenderungan berperilaku secara konsisten selaras dengan kepercayaan dan perasaan ini membentuk sikap individual. Karena itu adalah logis untuk mengharapkan bahwa sikap seseorang akan dicerminkannya dalam bentuk tendensi perilaku terhadap objek. Konsistensi antara kepercayaan sebagai komponen kognitif, perasaan sebagai komponen afektif, dengan tendensi perilaku sebagai komponen konatif seperti itulah yang menjadi landasan dalam usaha penyimpulan sikap yang dicerminkan oleh jawaban terhadap skala sikap.

\section{Komponen Komponen Sikap}

Pada hakikatnya sikap merupakan suatu interelasi dari berbagai komponen, dimana komponen-komponen tersebut Allport (dalam Mar'at, 1991) menyatakan bahwa ada tiga yaitu: (1) Komponen Kognitif, yaitu komponen yang tersusun atas dasar pengetahuan atau informasi yang dimiliki seseorang tentang objek sikapnya. Dari pengetahuan ini kemudian akan terbentuk suatu keyakinan tertentu tentang objek sikap tersebut. (2) Komponen Afektif, afektif berhubungan dengan rasa senang dan tidak senang. Jadi sifatnya evaluatif yang 


\section{MEDIKORA Vol. XIV No. 1April 2015}

berhubungan erat dengan nilai-nilai kebudayaan atau sistem nilai yang dimilikinya. (3) Komponen Konatif, yaitu merupakan kesiapan seseorang untuk bertingkah laku yang berhubungan dengan obyek sikapnya.

\section{Latihan}

Latihan adalah suatu proses yang sistematis secara berulang- ulang, secara tetap dengan selalu memberikan peningkatan beban. Menurut Djoko Pekik I (2006: 12) Latihan kebugaran diartikan sebagai proses sistematis menggunakan gerakan bertujuan meningkatkan atau mempertahankan kualitas fungsi tubuh yang mempunyai kualitas daya tahan paru-jantung, kekuatan dan daya tahan otot, kelentukan, dan komposisi tubuh. Menurut Dreger (2006) yang dikutip Suharjana (2007: 18) Latihan beban (weight training) adalah latihan yang sistematis yang menggunakan beban sebagai alat untuk menambah kekuatan otot guna mencapai tujuan seperti memperbaiki kondisi fisik atlit, mencegah terjadinya cedera atau untuk tujuan kesehatan.

Latihan merupakan aktivitas olahraga yang sistematik dalam waktu yang lama, ditingkatkan secara progresif dan individual yang mengarah pada fungsi psikologis dan fisiologis manusia untuk mencapai sasaran yang ditentukan (Suharjana, 2007: 13). Menurut Rusli Lutan (2002: 31) agar latihan sesuai dengan tujuan yang diinginkan maka harus memperhatikan frekuensi, intensitas, waktu, dan tipe.

Menurut Agus S (2007: 25) prinsip-prinsip latihan merupakan hal-hal yang harus ditaati, dilakukan atau dihindari agar tujuan latihan dapat tercapai sesuai yang diharapkan. Prinsipprinsip latihan mempunyai peranan penting terhadap aspek fisiologis dan psikologis olahragawan, dengan memahami prinsip-prinsip tersebut akan mendukung upaya dalam meningkatkan kualitas latihan, selain itu akan menghindarkan dari rasa sakit dan timbulnya cedera selama dalam proses latihan. Mengetahui bagaimana menerapkan prinsip-prinsip ini memberikan dasar pendidikan dimana dapat membuat keputusan tentang merancang suatu program kebugaran atau program latihan olahraga. Menurut Sudradjat (2000: 16) dalam pelaksanaan proses latihan salah satu hal yang harus dipegang secara teguh yaitu pengetahuan tentang prinsip-prinsip latihan.

Menurut Kravitz (2001: 20-21) latihan untuk meningkatkan kondisi kebugaran meliputi prinsip SPORT: specifity (kekhususan), Progresif (Peningkatan), overload (beban berlebih), reversibility (dapat kembali ke asal), training effect (efek latihan).

\section{Perencanaan program latihan}

Program latihan merupakan struktur untuk menetapkan tahapan program pelatihan 


\section{MEDIKORA Vol. XIV No. 1April 2015}

sebagai bagian dari rencana program pelatihan umum (total training). Program latihan merupakan kegiatan latihan yang dilaksanakan sehari-hari dengan berpedoman pada unit latihan harian yang telah dibuat atau direncanakan. Program latihan terencana atau sistematis yang berdasarkan pada prinsip latihan secara ilmiah berperan sangat fundamental bagi keberhasilan tujuan yang akan dicapai. (1) Analisis masalah, sebelum merancang program latihan kita harus mengetahui masalah yang dihadapi. Analisis masalah sangatlah penting dalam proses perencanaan program latihan. Dengan adanya masalah, itu akan mempermudah dalam proses perencanaan program latihan. (2) Perumusan rencana, perencanaan program latihan membutuhkan suatu pemahaman yang jelas mengenai tujuan dari program dan prosedur untuk meraih tujuan yang akan dicapai. Hal ini dapat dicapai dengan melaksanakan panduan sebagai berikut: (a) menetukan tujuan latihan, (b) menyusun rencana yang sistematis, (c) mengimplentasikan rencana tersebut, (d) Memonitor dan mengkaji ulang rencana tersebut. (2) Penjabaran rencana, penjabaran rencana program latihan adalah aspekaspek yang dikembangkan dari suatu perumusan rencana program latihan yang telah disusun.

(3) Pelaksanaan rencana, pelaksanaan rencana merupakan kegiatan latihan yang dilaksanakan sehari-hari dengan berpedoman pada unit latihan harian yang telah dibuat atau direncanakan. (5) Koreksi dan revisi, koreksi dan revisi adalah monitoring program latihan yang dilaksanakan dan membuat perubahan program latihan jika program mengindikasi kekurangan bahkan terjadi kegagalan. (6)Evaluasi hasil, evaluasi hasil adalah alat control untuk mengetahui sampai sejauh mana tingkat kemajuan yang dialami selama pelaksanaan latihan.

\section{METODE PENELITIAN}

Metode penelitian yang digunakan adalah metode survei dengan menggunakan angket. Populasi pada penelitian ini adalah member Fitness Center FIK UNY Yogyakarta. Sampel penelitian diambil dengan metode non probability sampling menggunakan teknik accidental sampling yaitu sampel yang diambil dari member Fitness Center FIK UNY Yogyakarta yang kebetulan bertemu saat latihan atau sedang dilakukan pengumpulan data. Sampel yang diambil sebanyak 40 member fitness FIK UNY Yogyakarta.

Instrumen yang digunakan dalam penelitian ini adalah angket. Angket atau kuisioner ini merupakan angket tertutup langsung dengan check list yang berisi pernyataan-pernyataan tentang sikap member fitness center terhadap program-program latihan dengan berdasarkan skala Likert yang telah dimodifikasi. Dalam skala Likert yang asli tingkat kesetujuan responden terhadap pernyataan dalam angket diklasifikasikan sebagai berikut: SS: 
Sangat Setuju, S: Setuju, BM: Belum Mengetahui/netral, TS: Tidak Setuju, STS: Sangat Tidak Setuju.

\section{HASIL PENELITIAN}

Data hasil penelitian terdiri dari variabel bebas yaitu sikapmember yang terdiri atas komponen kognitif, komponen afektif, komponen konatif serta variabel terikat yaitu program latihan kebugaran. Selain itu juga disajikan tabel distribusi frekuensi dan diagram batang dari distribusi frekuensi tiap-tiap variabel.

a. Variabel Komponen Kognitif

Data variabel komponen kognitif diperoleh melalui angket yang terdiri dari 14 item dengan jumlah responden 40 orang.Ada 4 alternatif jawaban di mana skor tertinggi 4 dan skor terendah 1. Berdasarkan data variabel komponen kognitif, diperoleh skor tertinggi sebesar 48,00 dan skor terendah sebesar 40,00. Hasil analisis harga mean(M) sebesar 43,7, median (Me) sebesar 44,00, modus (Mo) sebesar 44,00 dan standar deviasi(SD) sebesar 2,07.

Tabel 1. Distribusi Frekuensi Variabel Komponen Kognitif

\begin{tabular}{|c|c|c|c|c|c|}
\hline No. & \multicolumn{3}{|c|}{ Interv } & F & $\%$ \\
\hline 1 & 47,0 & - & 48,3 & 4 & 10 \\
\hline 2 & 45,6 & - & 46,9 & 3 & 7, \\
\hline 3 & 44,2 & - & 45,5 & 6 & 15 \\
\hline 4 & 42,8 & - & 44,1 & 1 & 37, \\
\hline 5 & 41,4 & - & 42,7 & 5 & 12 \\
\hline 6 & 40,0 & - & 41,3 & 7 & 17, \\
\hline \multicolumn{4}{|c|}{ Juml } & 4 & $100,0 \%$ \\
\hline
\end{tabular}

Mayoritas frekuensi variabel komponen kognitif terletak pada interval 42,844,1 sebanyak 15orang(37,5\%) dan paling sedikit terletak pada interval 45,5-46,9 masingmasing sebanyak 3 orang $(7,5 \%)$. Adapun hasil kategorisasi dapat dilihat pada tabel di bawah ini. 
Tabel 2. Distribusi Kategorisasi Variabel Komponen Kognitif

\begin{tabular}{|c|c|c|c|l|}
\hline \multirow{2}{*}{ No } & \multirow{2}{*}{ Skor } & \multicolumn{2}{|c|}{ Frekuensi } & \multirow{2}{*}{ Kategori } \\
\cline { 3 - 4 } & & Frekuensi & $\%$ & \\
\hline 1. & $76-100 \%$ & 40 & 10 & Sangat setuju \\
\hline 2. & $56-75 \%$ & 0 & 0 & Setuju \\
\hline 3. & $40-55 \%$ & 0 & 0 & Tidak setuju \\
\hline 4. & $<40 \%$ & 0 & 0 & Sangat tidak \\
\hline \multicolumn{2}{|r|}{} & 40 & 100,0 & \\
\hline
\end{tabular}

Faktor dominan pembentuk variabel komponen kognitif yang terdiri dari indikator pengetahuan, pandangan, keyakinandan akan disajikan sebagai berikut:

1) Pengetahuan

Data indikator pengetahuan diperoleh melalui angket yang terdiri dari 5 item dengan jumlah responden 40 orang. Ada 4 alternatif jawaban di mana skor tertinggi 4 dan skor terendah 1. Berdasarkan data indikator pada pengetahuan, diperoleh skor tertinggi sebesar 14,00 dan skor terendah sebesar 19,00. Hasil analisis harga mean (M) sebesar 17,025, median (Me) sebesar 17,00, modus (Mo) sebesar 18,00 dan standar deviasi (SD) sebesar 1,229.

Tabel 3. Distribusi Frekuensi Indikator Pengetahuan

\begin{tabular}{|c|c|c|c|c|c|}
\hline No. & \multicolumn{3}{|c|}{ Interval } & $\mathbf{F}$ & $\%$ \\
\hline 1 & 18,5 & - & 19,3 & 4 & 10 \\
\hline 2 & 17,6 & - & 18,4 & 12 & 30 \\
\hline 3 & 16,7 & - & 17,5 & 10 & 25 \\
\hline 4 & 15,8 & - & 16,6 & 10 & 25 \\
\hline 5 & 14,9 & - & 15,7 & 3 & 7,5 \\
\hline 6 & 14 & - & 14,8 & 1 & 2,5 \\
\hline \multicolumn{4}{|c|}{ Jumlah } & 40 & $100,00 \%$ \\
\hline
\end{tabular}

Adapun hasil kategorisasi dapat dilihat pada tabel di bawah ini.

Tabel 4. Distribusi Kategorisasi Indikator Pengetahuan

\begin{tabular}{|c|c|c|c|c|}
\hline \multirow[t]{2}{*}{ No } & \multirow[t]{2}{*}{ Skor } & \multicolumn{2}{|c|}{ Frekuensi } & \multirow[t]{2}{*}{ Kategori } \\
\hline & & Frekuensi & $\%$ & \\
\hline 1. & $76-100 \%$ & 36 & 90 & Sangat setuju \\
\hline 2. & $56-75 \%$ & 4 & 10 & Setuju \\
\hline 3. & $40-55 \%$ & 0 & 0 & Tidak setuju \\
\hline 4. & $<40 \%$ & 0 & 0 & Sangat tidak setuju \\
\hline & Total & 40 & 100,0 & \\
\hline
\end{tabular}


2) Pandangan

Data indikator pandangan diperoleh melalui angket yang terdiri dari 5item dengan jumlah responden 40 orang. Ada 4 alternatif jawaban di mana skor tertinggi 4 dan skor terendah 1.Berdasarkan data indikator pandangan, diperoleh skor tertinggi sebesar 20 dan skor terendah sebesar 14. Hasil analisis harga mean (M) sebesar 16,7, median (Me) sebesar 17,00, modus (Mo) sebesar 17,00 dan standar deviasi (SD) sebesar 1,522 .

\section{Tabel 5. Distribusi Frekuensi Indikator Pandangan}

\begin{tabular}{|c|c|c|c|c|c|}
\hline No. & \multicolumn{2}{|c|}{ Interval } & F & \% \\
\hline 1 & 19,5 & - & 20,5 & 2 & 5 \\
\hline 2 & 18,4 & - & 19,4 & 2 & 5 \\
\hline 3 & 17,3 & - & 18,3 & 8 & 20 \\
\hline 4 & 16,2 & - & 17,2 & 10 & 25 \\
\hline 5 & 15,1 & - & 16,1 & 9 & 22,5 \\
\hline 6 & 14 & - & 15 & 9 & 22,5 \\
\hline \multicolumn{2}{|c|}{ Jumlah } & 40 & $100,00 \%$ \\
\hline
\end{tabular}

Adapun hasil kategorisasi dapat dilihat pada tabel di bawah ini.

Tabel 6. Distribusi Kategorisasi Indikator Variabel Pandangan

\begin{tabular}{|c|c|c|c|c|}
\hline \multirow[t]{2}{*}{ No } & \multirow[t]{2}{*}{ Skor } & \multicolumn{2}{|c|}{ Frekuensi } & \multirow[t]{2}{*}{ Kategori } \\
\hline & & Frekuensi & $\%$ & \\
\hline 1. & $76-100 \%$ & 31 & 77,5 & Sangat setuju \\
\hline 2. & $56-75 \%$ & 9 & 22,5 & Setuju \\
\hline 3. & $40-55 \%$ & 0 & 0 & Tidak setuju \\
\hline 4. & $<40 \%$ & 0 & 0 & Sangat tidak setuju \\
\hline \multicolumn{2}{|r|}{ Total } & 40 & 100,0 & \\
\hline
\end{tabular}

3) Keyakinan

Data indikator keyakinan diperoleh melalui angket yang terdiri dari 4 item dengan jumlah responden 40 orang.Ada 4 alternatif jawaban di mana skor tertinggi 4 dan skor terendah 1. Berdasarkan data indikator keyakinan, diperoleh skor tertinggi sebesar 12,00 dan skor terendah sebesar 6,00. Hasil analisis harga mean (M) sebesar 9,975, median (Me) sebesar 10, modus (Mo) sebesar 9,00 dan standar deviasi (SD) sebesar 1,29.

Tabel 7. Distribusi Frekuensi Indikator Keyakinan

\begin{tabular}{|l|l|c|c|}
\hline No. & Interval & F & $\%$ \\
\hline
\end{tabular}




\begin{tabular}{|c|c|c|c|c|c|}
\hline 1 & 11.5 & - & 12.5 & 5 & 12.5 \\
\hline 2 & 10,4 & - & 11,4 & 9 & 22,5 \\
\hline 3 & 9,3 & - & 10,3 & 11 & 27,5 \\
\hline 4 & 8,2 & - & 9,2 & 12 & 30 \\
\hline 5 & 7,1 & - & 8,1 & 2 & 5 \\
\hline 6 & 6 & - & 7 & 1 & 2,5 \\
\hline \multicolumn{2}{|c|}{ Jumlah } & & 108 & $100,00 \%$ \\
\hline
\end{tabular}

Adapun hasil kategorisasi dapat dilihat pada tabel di bawah ini.

Tabel 8. Distribusi Kategorisasi Indikator Keyakinan

\begin{tabular}{|c|c|c|c|l|}
\hline \multirow{2}{*}{ No } & Skor & \multicolumn{2}{|c|}{ Frekuensi } & \multirow{2}{*}{ Kategori } \\
\cline { 3 - 5 } & & Frekuensi & $\%$ & \\
\hline 1. & $76-100 \%$ & 25 & 62,5 & Sangat setuju \\
\hline 2. & $56-75 \%$ & 14 & 35 & Setuju \\
\hline 3. & $40-55 \%$ & 0 & 0 & Tidak setuju \\
\hline 4. & $<40 \%$ & 40 & 100,0 & \\
\hline \multicolumn{2}{|r|}{} & Total & & \\
\hline
\end{tabular}

b. Variabel Komponen Afektif

Data variabel komponen afektif diperoleh melalui angket yang terdiri dari 15 item dengan jumlah responden 40 orang. Ada 4 alternatif jawaban di mana skor tertinggi 4 dan skor terendah 1. Berdasarkan data variabel komponen afektif, diperoleh skor tertinggi sebesar 53,00 dan skor terendah sebesar 38,00. Hasil analisis harga mean (M) sebesar 45,575, median (Me) sebesar 45,00, modus (Mo) sebesar 44,00 dan standar deviasi (SD) sebesar 3,257

Tabel 9. Distribusi Frekuensi Variabel Komponen Afektif

\begin{tabular}{|c|c|c|c|c|c|}
\hline No. & \multicolumn{3}{|c|}{ Interval } & F & $\%$ \\
\hline 1 & 51,0 & - & 53,5 & 4 & 10,0 \\
\hline 2 & 48,4 & - & 50,9 & 3 & 7,5 \\
\hline 3 & 45,8 & - & 48,3 & 12 & 30 \\
\hline 4 & 43,2 & - & 45,7 & 12 & 30 \\
\hline 5 & 40,6 & - & 43,1 & 8 & 20 \\
\hline 6 & 38 & - & 40,5 & 1 & 2,5 \\
\hline \multicolumn{2}{|c|}{ Jumlah } & 40 & $100,0 \%$ \\
\hline
\end{tabular}

Adapun hasil kategorisasi dapat dilihat pada tabel di bawah ini.

Tabel 10. Distribusi Kategorisasi Variabel Komponen Afektif

\begin{tabular}{|c|c|c|c|}
\hline \multirow[t]{2}{*}{ No } & \multirow[t]{2}{*}{ Skor } & Frekuensi & \multirow[t]{2}{*}{ Kategori } \\
\hline & & Frekuensi & \\
\hline
\end{tabular}




\begin{tabular}{|c|c|c|c|l|}
\hline 1. & $76-100 \%$ & 19 & 47,5 & Sangat setuju \\
\hline 2. & $56-75 \%$ & 21 & 52,5 & Setuju \\
\hline 3. & $40-55 \%$ & 0 & 0 & Tidak setuju \\
\hline 4. & $<40 \%$ & 0 & 0 & Sangat tidak setuju \\
\hline & Total & 40 & 100,0 & \\
\hline
\end{tabular}

Faktor dominan pembentuk variabel komponen afektif yang terdiri dari indikator perasaan senang dan perasaan tidak senang akan disajikan sebagai berikut:

1) Perasaan senang

Data indikator perasaan senang diperoleh melalui angket yang terdiri dari 7 item dengan jumlah responden 40 orang. Ada 4 alternatif jawaban di mana skor tertinggi 4 dan skor terendah 1 . Berdasarkan data indikator pada perasaan senang, diperoleh skor tertinggi sebesar 28,00 dan skor terendah sebesar 18,00. Hasil analisis harga mean (M) sebesar 22,425, median (Me) sebesar 22, modus (Mo) sebesar 21,00 dan standar deviasi (SD) sebesar 2,427.

Tabel 10. Distribusi Frekuensi Indikator Perasaan senang

\begin{tabular}{|c|c|c|c|c|c|}
\hline No. & \multicolumn{3}{|c|}{ Interval } & F & \% \\
\hline 1 & 26,5 & - & 28,1 & 3 & 7,5 \\
\hline 2 & 24,8 & - & 26,4 & 4 & 10 \\
\hline 3 & 23,1 & - & 24,7 & 6 & 15 \\
\hline 4 & 21,4 & - & 23 & 10 & 25 \\
\hline 5 & 19,7 & - & 21,3 & 13 & 32,5 \\
\hline 6 & 18 & - & 19,6 & 4 & 10 \\
\hline \multicolumn{2}{|c|}{ Jumlah } & 40 & $100,00 \%$ \\
\hline
\end{tabular}

Adapun hasil kategorisasi dapat dilihat pada tabel di bawah ini.

Tabel 11. Distribusi Kategorisasi Indikator Perasaan senang

\begin{tabular}{|c|c|c|c|c|}
\hline \multirow[t]{2}{*}{ No } & \multirow[t]{2}{*}{ Skor } & \multicolumn{2}{|c|}{ Frekuensi } & \multirow[t]{2}{*}{ Kategori } \\
\hline & & Frekuensi & $\%$ & \\
\hline 1. & $76-100 \%$ & 23 & 57,5 & Sangat setuju \\
\hline 2. & $56-75 \%$ & 17 & 42,5 & Setuju \\
\hline 3. & $40-55 \%$ & 0 & 0 & Tidak setuju \\
\hline 4. & $<40 \%$ & 0 & 0 & Sangat tidak setuju \\
\hline \multicolumn{2}{|r|}{ Total } & 40 & 100,0 & \\
\hline
\end{tabular}

2) Perasaan Tidak senang

Data indikator perasaan tidak senang diperoleh melalui angket yang terdiri dari 8 
item dengan jumlah responden 40 orang. Ada 4 alternatif jawaban di mana skor tertinggi 4 dan skor terendah 1. Berdasarkan data indikator perasaan tidak senang, diperoleh skor tertinggi sebesar 29 dan skor terendah sebesar 19.

Tabel 12. Distribusi Frekuensi Indikator Perasaan Tidak Senang

\begin{tabular}{|c|c|c|c|c|c|}
\hline No. & \multicolumn{3}{|c|}{ Interval } & F & $\%$ \\
\hline 1 & 27,5 & - & 29,1 & 3 & 7,5 \\
\hline 2 & 25,8 & - & 27,4 & 1 & 2,5 \\
\hline 3 & 24,1 & - & 25,7 & 7 & 17,5 \\
\hline 4 & 22,4 & - & 24 & 11 & 27,5 \\
\hline 5 & 20,7 & - & 22,3 & 13 & 32,5 \\
\hline 6 & 19 & - & 20,6 & 5 & 12,5 \\
\hline \multicolumn{2}{|c|}{ Jumlah } & & 40 & $100,00 \%$ \\
\hline
\end{tabular}

Tabel 13. Distribusi Kategorisasi Indikator Variabel Perasaan Tidak Senang

\begin{tabular}{|l|c|c|c|l|}
\hline \multirow{2}{*}{ No } & Skor & \multicolumn{2}{|c|}{ Frekuensi } & \multirow{2}{*}{ Kategori } \\
\cline { 2 - 4 } & & Frekuensi & $\%$ & \\
\hline 1. & $76-100 \%$ & 11 & 27,5 & Sangat setuju \\
\hline 2. & $56-75 \%$ & 29 & 72,5 & Setuju \\
\hline 3. & $40-55 \%$ & 0 & 0 & Tidak setuju \\
\hline 4. & $<40 \%$ & 0 & 0 & Sangat tidak setuju \\
\hline \multicolumn{2}{|l|}{} & 40 & 100,0 & \\
\hline
\end{tabular}

c. Variabel Komponen Konatif

Data variabel komponen konatif diperoleh melalui angket yang terdiri dari 9 item dengan jumlah responden 40 orang. Ada 4 alternatif jawaban di mana skor tertinggi 4 dan skor terendah 1. Berdasarkan data variabel komponen konatif diperoleh skor tertinggi sebesar 37,00 dan skor terendah sebesar 28,00.

\section{Tabel 14. Distribusi Frekuensi Variabel Komponen Konatif}

\begin{tabular}{|c|c|c|c|c|c|}
\hline No. & \multicolumn{3}{|c|}{ Interval } & F & $\%$ \\
\hline 1 & 36 & - & 37,5 & 4 & 10,0 \\
\hline 2 & 34,4 & - & 35,9 & 5 & 12,5 \\
\hline 3 & 32,8 & - & 34,3 & 12 & 30 \\
\hline 4 & 31,2 & - & 32,7 & 2 & 5 \\
\hline 5 & 29,6 & - & 31,1 & 15 & 37,5 \\
\hline 6 & 28 & - & 29,5 & 2 & 5 \\
\hline
\end{tabular}


Jumlah

40

$100,0 \%$

Tabel 15. Distribusi Kategorisasi Variabel Komponen Konatif

\begin{tabular}{|c|c|c|c|l|}
\hline \multirow{2}{*}{ No } & \multirow{2}{*}{ Skor } & \multicolumn{2}{|c|}{ Frekuensi } & \multirow{2}{*}{ Kategori } \\
\cline { 2 - 4 } & & Frekuensi & $\%$ & \\
\hline 1. & $76-100 \%$ & 32 & 80 & Sangat setuju \\
\hline 2. & $56-75 \%$ & 8 & 20 & Setuju \\
\hline 3. & $40-55 \%$ & 0 & 0 & Tidak setuju \\
\hline 4. & $<40 \%$ & 0 & 0 & Sangat tidak setuju \\
\hline & Total & 40 & 100,0 & \\
\hline
\end{tabular}

d. Variabel Sikap Member Fitness

Data variabel sikap member fitness diperoleh melalui angket yang terdiri dari 38 item dengan jumlah responden 40 orang. Ada 4 alternatif jawaban di mana skor tertinggi 4 dan skor terendah 1. Berdasarkan data variabel sikap member fitness diperoleh skor tertinggi sebesar 135,00 dan skor terendah sebesar 107,00.

Tabel 16. Distribusi Frekuensi Variabel Sikap Member Fitness

\begin{tabular}{|c|c|c|c|c|c|}
\hline No. & \multicolumn{3}{|c|}{ Interval } & F & $\%$ \\
\hline 1 & 130,5 & - & 135,1 & 2 & 5 \\
\hline 2 & 125,8 & - & 130,4 & 8 & 20 \\
\hline 3 & 121,1 & - & 125,7 & 11 & 27,5 \\
\hline 4 & 116,4 & - & 121 & 12 & 30 \\
\hline 5 & 111,7 & - & 116,3 & 6 & 15 \\
\hline 6 & 107 & - & 111,6 & 1 & 2,5 \\
\hline \multicolumn{4}{|c|}{ Jumlah } & 40 & $100,0 \%$ \\
\hline
\end{tabular}

Tabel 17. Distribusi Kategorisasi Variabel Sikap Member Fitness

\begin{tabular}{|c|c|c|c|c|}
\hline \multirow[t]{2}{*}{ No } & \multirow[t]{2}{*}{ Skor } & \multicolumn{2}{|c|}{ Frekuensi } & \multirow[t]{2}{*}{ Kategori } \\
\hline & & Frekuensi & $\%$ & \\
\hline 1. & $76-100 \%$ & 33 & 82,5 & Sangat setuju \\
\hline 2. & $56-75 \%$ & 7 & 17,5 & Setuju \\
\hline 3. & $40-55 \%$ & 0 & 0 & Tidak setuju \\
\hline 4. & $<40 \%$ & 0 & 0 & Sangat tidak setuju \\
\hline & Total & 40 & 100,0 & \\
\hline
\end{tabular}

\section{PEMBAHASAN}

Hasil perhitungan dengan bantuan SPSS Versi 13.0 diperoleh data sikap member fitness center GOR FIK UNY Yogyakarta dengan jumlah responden 40 siswa, yang masuk dalam variabel sikap member fitness dalam kategorisangat setuju sebanyak 33 orang (82,5\%) dan 


\section{MEDIKORA Vol. XIV No. 1April 2015}

frekuensi variabel sikap member fitness pada kategori setuju sebanyak 7 orang (17,5\%). Data tersebut menunjukkan bahwa kecenderungan data berpusat pada kategori sangat setuju. Dengan demikian dapat disimpulkan bahwa sikap member fitness center di GOR FIK UNY Yogyakarta termasuk dalam kategori sangat setuju.

Sikap setiap orang terhadap suatu objek berbeda-beda. Sama hal nya dengan sikap member fitness terhadap program latihan di fitness center pasti tidak akan sama. sikap seseorang bisa diukur dengan tiga komponen yaitu komponen kognitif, dimana komponen ini berkaitan dengan pengetahuan, pandangan, dan keyakinan member fitness terhadap program latihan. Kedua komponen afektif, berhubungan dengan rasa senang dan tidak senang member terhadap program latihan. Sifatnya evaluatif yang berhubungan erat dengan nilai-nilai kebudayaan atau sistem nilai yang dimilikinya. Ketiga komponen konatif, yaitu sikap atau perilaku member terhadap objek yang diterima, objek disini adalah program latihan.

Program latihan sangat penting sebagai acuan untuk melaksanakan dan mengendalikan suatu proses latihan. Program latihan sangat bermanfaat dalam pelaksanaan latihan kebugaran jasmani.Berdasarkan program latihan tersebut maka latihan lebih terarah dan lebih efektif dalam pelaksanaannya.program latihan merupakan hal-hal yang harus dilaksanakan agar tujuan latihan dapat tercapai sesuai dengan yang diharapkan. program latihan mempunyai peranan penting terhadap keberhasilan latihan. Program latihan penting untuk diketahui dan diterapkan masyarakat dalam latihan beban, dengan memahami program-program latihan tersebut masyarakat pelaku olahraga bisa untuk terus berolahraga dan meningkatkan kesadaran melakukan olahraga dengan acuan tersebut, sehingga latihan yang dilakukan akan mendapatkan hasil yang diinginkan. Latihan yang dilakukan sesuai program-program tersebut akan mendukung upaya dalam meningkatkan kualitas latihan, selain itu akan menghindarkan pelaku olahraga dari rasa sakit dan timbulnya cedera selama dalam proses latihan.

\section{KESIMPULAN}

Berdasarkan hasil penelitian dan pembahasan tentang "Sikap Member Fitness Center GOR FIK UNY Yogyakarta terhadap program-program latihan kebugaran” dapat ditarik kesimpulan sebagai berikut:

1. Secara keseluruhan dari ketiga komponen, yaitu komponen kognitif, komponen afektif, dan komponen konatif atau perilaku, sikap member Fitness Center GOR FIK UNY Yogyakarta terhadap program-program latihan adalah positif. 


\section{MEDIKORA Vol. XIV No. 1April 2015}

2. Member Fitness Center GOR FIK UNY Yogyakarta, sudah memiliki pemahaman bahwa program-program latihan penting dalam menunjang keberhasilan latihan.

3. Member Fitness Center GOR FIK UNY Yogyakarta, mayoritas telah melaksanakan program latihan yang diberikan oleh instruktur.

4. Program-program latihan merupakan pedoman bagi setiap member fitness center sebelum melaksanakan latihan, agar tujuan yang diharapkan bisa tercapai.

\section{DAFTAR PUSTAKA}

Allport (dalam Mar'at). (1991). Jum'at, 02 Maret 2012. Error! Hyperlink reference not valid.sikap.html.

Djoko Pekik Irianto. (2006). Bugar dan Sehat dengan Berolahraga. Yogyakarta: Andi Offset.

Kravitz. (2001). Panduan Lengkap Bugar Total. Jakarta: PT Raja Gravindo

Rusli Lutan. (2002). Menuju Sehat dan Bugar. Jakarta. Depdiknas.

Saifuddin Azwar. (1995). Sikap Manusia. Yogyakarta: Pustaka Pelajar Offset.

Suharjana. (2007). Latihan Beban. Yogyakarta: FIK UNY.

Sumarjo dan Suharjana. (2007). "Sikap Pelajar SMA Negeri di Daerah Istimewa Yogyakarta terhadap Olahraga.” Laporan Penelitian. Yogyakarta: FIK UNY.

Wade dan Travis. (2007). http://www.blogspot.com/makalah cyber/kognisi, emosi dan motivasi dalam konseling. html. Miinggu, 12 November 2012Tri Rusmi Widayatun. (1999). Ilmu Perilaku. Jakarta: CV Sagung Seto.

www.Britannica.com /Principles -of -execise- training.html. Prinsip-prinsip Latihan. Jum'at, 02 Maret 2012. 